vessels extending a short distance from its periphery. In many animals the optic disc is deeply excavated up to its margins, and resembles that of chronic glaucoma in the human subject, a state of which the best examples are furnished by the seal, the serval, and the red and white flying-squirrel. The condition presented by the rabbit, in which some of the fibres of the optic nerve carry their sheaths through the lamina cribrosa to form an opaque patch on the retina, is met with in many other animals, but with much variety in the depth and distribution of the opacity.

The coloration of the tapetum varies greatly in different animals ; and Dr. Johnson calls particular attention to his drawing of the eye of Monteiro's galago, in which the general yellow of the central part of the fundus is surrounded by a zone of pigmentation precisely resembling what is called "pigmentary retinitis " in the human subject. Dr. Johnson inclines to the belief that the affection so described is not really a disease, but rather a reversion to a type of structure which is the rule in night-seeing animals.

It is impossible to withhold a tribute of admiration from the perseverance with which Dr. Johnson has conducted his researches, or from the beauty of the drawings in which the results of his observations are displayed; but it is for the moment necessary to retain a suspended judgment with regard to the value of his work. As an observer he stands alone ; and the drawings which he has made, notwithstanding their great and obvious merit, are as yet mere personal records, liable, it may be, to some disturbing influence from a personal equation. It is much to be regretted that photography has not been made available for taking pictures of the eyeground from which this element of uncertainty would be removed. Even if this were done, it would still be necessary to determine, by more extended portraiture, whether the conditions described are normal ones or subject to variation in individuals. We cordially welcome Dr. Johnson as a pioneer, and we feel sure that he will fully appreciate the necessity for caution in accepting his conclusions.

\section{THE COAL-TAR COLOUR INDUSTRY IN GERMANY AND ENGLAND.}

WITH the object of ascertaining our present and future prospects in the chemical trade of the world, Mr. A. G. Green, in a paper read before the section of chemistry of the British Association, at this year's meeting, described the relative progress of the coal-tar industry in England and Germany during the past fifteen years. The council decided to print the paper in extenso, and the subjoined particulars extracted from it convey an idea of what England has lost by the neglect of the scientific foundations of an industry. The paper may be regarded as a sequel to one by Prof. Meldola published in NATURE fifteen years ago (vol. xxxiv. p. 324), when the position of the industry in Germany and England was described, and a warning was given to British manufacturers.

The exports of coal-tar colours manufactured in England have fallen from $530,000 l$. in 1890 to $366,500 l$. in 1899 . Comparing these figures with the rapidly increasing export trade of Germany, it is seen that whereas formerly the English export trade in artificial colours was about one-quarter that of Germany, it does not now amount to a tenth part. It is therefore only too apparent that we have had but little share in the great increase which this industry has experienced during the past fifteen years, and that we have not even been able to supply the expansion in our own requirements. In order to ascertain what proportion of our own needs we at present furnish, I am able to lay before you the following interesting figures, which have been kindly supplied me by the Bradford Dyers' Association and the British Cotton and Wool Dyers' Association, who together form a very large proportion of the entire dyeing trade :-

Colouring Matters used by Bradford Dyers' Association.

English, ro per cent. ; German, 80 per cent. ; Swiss, 6 per cent, ; French, 4 per cent.

\section{Colouring Matters used by British Cotton and Wool Dyers'} Association.

Aniline Colours.-English, 22 per cent.; foreign, 78 per cent.

Alizarine Colours. -English, I'65 per cent. ; foreign, 98.35 per cent.

No. 1676, voL. 65$]$
The English Sewing Cotton Company have also very kindly supplied me with a detailed analysis of their consumption, from which it appears that out of a total of sixty tons of colouring matters and other dyeing materials derived from coal tar, only 9 per cent. were of English manufacture.

The following table of statistics of the six largest German firms gives a fair picture of the present dimensions of the industry in that country (vide next page).

The joint capital of these six firms amounts to at least $2 \frac{1}{2}$ millions. They employ together about 500 chemists, 350 engineers and other technologists, 1360 business managers, clerks, travellers, \&c., and more than 18,000 workpeople. Compared with such figures as these the English colour manufacture assumes insignificant proportions. The total capital invested in the coal-tar colour trade in England probably does not exceed $500,000 l$., the total number of chemists employed cannot be more than thirty or forty, and the number of workmen engaged in the manufacture does not amount to more than a thousand.

A similar relative proportion is maintained in the number of patents for new colouring matters and other coal-tar products taken by the English and German firms, as is shown by the following table :-

Comparison of Number of Completed English Patents for Coaltar Products taken during I886-1900 by six largest English and six largest German Firms.

German Firms.

$\begin{array}{lllllll}\text { Badische Aniline Works } & \ldots & \ldots & \ldots & \ldots & \ldots & \mathbf{1} 79\end{array}$

Meister, Lucius, \& Brüning ...

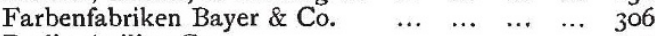

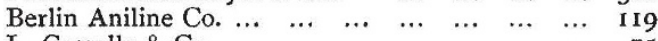

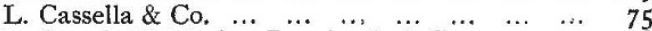

Farbwerk Mühlheim, Leonhardt \& Co. $\quad . . \quad \ldots . \quad 3^{8}$

Total of six German firms $\quad \ldots \quad \ldots \quad \ldots \quad 948$ English Firms.

$\begin{array}{llllll}\text { Brooke, Simpson, and Spiller } & \ldots & \ldots & \ldots & \ldots & 7\end{array}$

$\begin{array}{llllllll}\text { Clayton Aniline Co. } & \ldots & \ldots & \ldots & \ldots & \ldots & \ldots & 2 \text { I }\end{array}$

$\begin{array}{llllllllll}\text { Levinstein } & \cdots & \ldots & \ldots & \ldots & \ldots & \ldots & \ldots & \ldots & 19\end{array}$

Read, Holliday, \& Co. ...

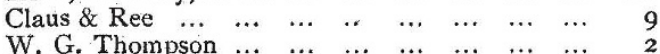

Total of six English firms $\quad \ldots \quad \ldots \quad \ldots \quad 86$

Nor does the potential loss which we have sustained by our inability to take advantage of a growing industry represent the sum total of our losses. The new colouring matters, made almost exclusively in Germany, have in many cases been introduced as substitutes for natural products, which were staple articles of English commerce. Madder and cochineal have been replaced by alizarine and azo-scarlets, the employment of many dyewoods has greatly decreased, whilst at the present moment logwood and indigo are seriously threatened. Regarding the indigo question so much has been written that I do not propose to occupy space in its further discussion, but will only point out that the complete capture of the indigo market by the synthetic product, which would mean a loss to our Indian dependencies of $3,000,000$. a year, is regarded by the Badische Company as so absolutely certain that, having already invested nearly a million pounds in the enterprise, they are at present issuing $750,000 \%$. of new debenture capital to provide funds to extend their plant for this purpose! In the last annual report of the company they say: "As regards plant indigo, the directors are prepared and determined to meet this competition in all its possible variations in value. Much strange matter has been published in India as to improvements in the cultivation and preparation of natural indigo, but the illusions of the planters and indigo dealers are destined to be dispelled before facts, which, although they are not known to them, will make themselves more felt the larger the production of artificial indigo becomes."

Besides the loss of material wealth which the neglect of the coal-tar trade has involved to the country, there is yet another aspect of the question which is even of more importance than the commercial one. There can be no question that the growth in Germany of a highly scientific industry of large and far-reaching proportions has had an enormous effect in encouraging and stimulating scientific culture and scientific research in all 
Fosition of the Six Largest Colour Works in Germany in Year 1900.

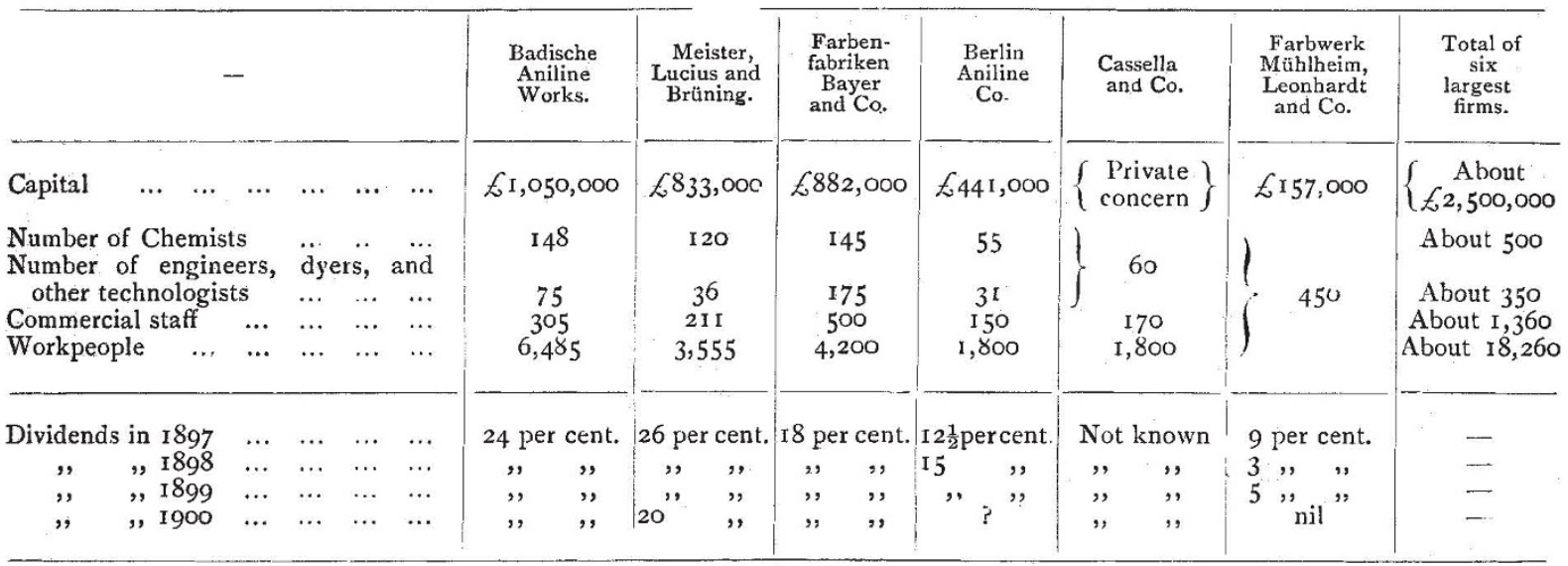

branches of knuwledge. It has reacted with beneficial effect upon the universities, and has tended to promote scientific thought throughout the land. By its demonstration of the practical importance of purely theoretical conceptions it has had a far-reaching effect on the intellectual life of the nation. How much such a scientific revival is wanted in our country the social and economic history of the past ten years abundantly testifies.

\section{UNIVERSITY AND EDUCATIONAL INTELLIGENCE.}

CAMBRIDGE. - An interesting ceremony took place on Saturday last, when a portrait of Prof. G. D. Liveing, painted by Sir John Reid, president of the Royal Scottish Academy, was presented to St. John's College as a mark of recognition of Prof. Liveing's services to science. The portrait was provided by subscription, and the funds obtained will also enable a bronze bust of Prof. Liveing to be placed in the Chemical Laboratory at Cambridge. The Vice-Chancellor (Dr. Ward, Master of Peterhouse) presided at the meeting of subscribers, and the attendance included the Lord Lieutenant, Sir John Gorst, Sir Richard Jebb, the Masters of Trinity, St. John's, Clare, Jesus, Christ's, and Downing, Profs. Sir George Stokes, E. C. Clark, J. Dewar, W. J. Lewis, A. R. Forsyth, J. Westlake, J. J. Thomson, J. A. Ewing, W. W. Skeat and J. S. Reid, besides many other resident members of the Senate.

PrinCIPAL RÜCKER, F.R.S., will distribute the prizes and certificates to students of the South-Western Polytechnic, Chelsea, to-morrow evening, December 13. The chair will he taken by Mr. Sidney Webb.

Prof. EDgar Crookshank, who lately resigned the active duties of the chair of comparative pathology and bacteriology in King's College, London, which he occupied for fifteen years, has had the title of Emeritus Professor conferred upon him by the Council in consideration of his long and brilliant services.

THE St. Petersburg correspondent of the Times states that the Minister of Public Instruction has made a decree expelling ali the first-year students at the Kharkoff Veterinary Institute for insulting the professor of chemistry at that college. The reason for this action on the part of the Minister is the fact that on November 28 the first-year students sent a signed request to the professor of chemistry that he should resign his chair on the ground that his teaching was unsystematic and obscure. The decree adds that the professorial staff were agreed that the charge against their colleague was without foundation.

THE British Medical Tournal states that the municipality of Hamburg has adopted a scheme by which all the scientific institutions of the city are to be grouped together into a university. The directors of these institutes and the lecturers, who have the title of professors, will form the professorial college, No. I 676 , voL. 65$]$ which every year will elect its own president. It will also be the duty of the college every year to draw up a programme of lectures and practical courses. The programme for the current winter semester includes courses by $I I 7$ lecturers. This movement is a step towards the foundation of a fully-equipped university in Hamburg, a project which has long been under consideration.

AFTER a meeting of the U.S. Cabinet on Tuesday it was stated that the President had received a communication from Mr. Carnegie on the subject of the creation of a fund for the extension of higher education. The amount said to have been offered is ten million dollars. It is understood (says the Times correspondent at Washington) that the proposal does not involve the establishment of university buildings at Washington, but that it is intended rather to place a fund in the hands of Government trustees, from which the expenses of deserving students may be paid for the encouragement of original research at home or abroad. It is believed that the proposal has not yet taken concrete form, except as regards its general terms and the amount of the gift. The President will consult with members of Congress with regard to the proposed gift before making its terms public.

Mr. Hanbury, President of the Board of Agriculture, distributed the prizes at the Derby Municipal Technical College last week, and gave an address upon some aspects of technical edu. cation. In the course of his address he remarked that he believed that partly where the United States and Germany had the ad. vantage of England was not in the technical education of their working classes, but among the great leaders of commerce and industry. Commercial education must spread from the top to the bottom. They wanted to have commercial instincts and business capacity instilled into their leading commercial men, even up to the universities themselves. England was far behind America in that respect. Twenty years ago there was only one college of the kind to which he referred in the States, and that was in Pennsylvania; now there were at least nine or ten universities in the Union which were giving that commercial education to the leaders of the country's commerce and industry. It was, unfortunately, the fact that they were lacking in a good system of secondary education. He hoped something would be done in the matter in the next session of Parliament. The foundation for the work of technical schools was a good, sound education which could only be obtained in the secondary schools. This was the reason why at the present moment they did not find in technical schools those advanced students and day scholars which he hoped, under the new system, they would find flocking into them.

THE movement in favour of reformed methods of mathe matical teaching can be assisted by discussions at provincial scientific societies and university centres. A discussion of this kind took place at the meeting of the Royal Glasgow Philosophical Society, held on December 6. Prof. Gray being in the chair, when the subject of the teaching of mathematics to engineers was opened by Prof. Barr. It was remarked by him that the engineer uses mathematics as a tool, and it is not essential for the man who uses tools to manufacture them. He did 